\title{
Acquired B antigen in ABO blood group system: Non-secretor group 'Al' subtype, Rh positive with auto antibodies in a patient with urinary tract infection with E. coli
}

\author{
Bipin Nepal' ${ }^{1}$, MD; Bikash Shrestha², MD; Ravi Mahat ${ }^{3}$, FCPS; Abish Adhikari ${ }^{4}$ MD \\ ${ }^{1}$ Department of Transfusion Medicine, Grande International Hospital, Kathmandu, Nepal \\ ${ }^{2}$ Department of Wellness \& Family Medicine, Grande International Hospital \\ ${ }^{3}$ Department of Pulmonology, Grande International Hospital \\ ${ }^{4}$ Department of Oncology, Grande International Hospital
}

Corresponding author

Bipin Nepal, MD

Email: nepalbipin@hotmail.com

Received 5 Dec 2018

Accepted 14 Dec 2018

\section{ABSTRACT}

This is case report of a female with " $\mathrm{A}$ " sub type with acquired B antigen and non-secretor status, first ever reported with this combination in Nepal, during blood grouping of a sample of a patient with urinary tract infection. The patient was referred to our center for blood grouping, cross matching and transfusion due to severe anemia.

During routine blood grouping, the red cells showed mixed field agglutination with anti-A, anti$A B$ and microscopic agglutination with anti-B. On serum grouping, we detected potent Anti-B and no agglutination with anti-A. There was no reaction with anti-A both at room temperature and at $37^{\circ} \mathrm{C}$. Her cells were further tested with $\mathrm{A} 1 \mathrm{Lectin}$ and $\mathrm{Anti}-\mathrm{H}$ antisera. There was strong reaction with $\mathrm{A} 1$ Lectin and 3+ macroscopic reaction with anti- $\mathrm{H}$ in addition to a positive auto-control. Her direct antiglobulin test was only +1 positive. For her " $\mathrm{B}$ " antigen, we acidified $\mathrm{B}$ antisera with $\mathrm{HCl}$, which did not give any macro or microscopic agglutination with patient's red cells. Her "Rh" status was positive and on examining the saliva, she was found to be non-secretor.

The first choice of blood group for transfusion in this case is the "A1" sub type followed by "O" blood group. As the patient had already received " $\mathrm{A}$ " blood group and in the presence of auto antibodies, " $\mathrm{A}$ subgroup" blood transfusion should be avoided in her.

Keywords: ABO blood grouping, A sub-group, Acquired B antigen

\section{Introduction:}

The $A B O$ blood group system was the first to be discovered and till now remains the most important in transfusion practice. This is due to regular occurrence of Anti-A, anti-B \& anti-AB antibodies, reactive at $37^{\circ} \mathrm{C}$, capable of causing red cell destruction in persons whose red cells lack the corresponding antigens. There are over $70 \mathrm{ABO}$ alleles reported to date highlighting the extensive sequence variation in the coding region of the gene $^{1}$. A3 (subgroup of $A$ ) is a rare phenotype of blood usually due to allelic difference at " $\mathrm{A}$ " locus especially at $7^{\text {th }}$ exon ${ }^{2}$. Many of these subgroups can be wrongly typed as ' $O$ ' because the " $A$ " antigen is very weakly present on red cell membrane, which cannot be detected if weak anti-A is used in cell typing $^{3}$. Most of the ABO blood group antibodies are IgM in nature and detected best at $4^{\circ} \mathrm{C}$. Many blood banks perform blood groups only by forward grouping and these results are not counter checked by reverse grouping. In addition, some may use tile method in which weak antigens are not detected and as a result the persons are typed wrongly. 
Nepal, et al. / Acquired B antigen in ABO blood group system: Non-secretor group 'A1'subtype, Rh positive with auto antibodies in a patient with urinary tract infection with $\mathrm{E}$. coli

Table 1: Various reactions of "A" sub-groups

\begin{tabular}{|c|c|c|c|c|c|c|c|c|c|c|c|}
\hline $\begin{array}{l}\text { Sub } \\
\text { group }\end{array}$ & $\begin{array}{c}\text { Anti } \\
\text { A }\end{array}$ & $\begin{array}{c}\text { Anti } \\
\text { B }\end{array}$ & $\begin{array}{c}\text { Anti } \\
A B\end{array}$ & $\begin{array}{c}\text { Anti } \\
\text { H }\end{array}$ & $\begin{array}{c}\text { A1 } \\
\text { lectin }\end{array}$ & A cells & $\begin{array}{l}\text { B } \\
\text { cells }\end{array}$ & $\begin{array}{l}\text { Secretor } \\
\text { status }\end{array}$ & $\begin{array}{c}\text { "A" } \\
\text { Transferase }\end{array}$ & $\begin{array}{l}\text { Antigen: } \\
\text { RBCs } \times 10^{3}\end{array}$ & $\begin{array}{l}\text { serum } \\
\text { Antibody }\end{array}$ \\
\hline $\mathrm{A}_{2}$ & +2 & $++m f$ & $. w k / 0$ & $\mathrm{mf}$ & 0 & $+1-$ & Yes & A, $\mathrm{H}$ & Yes & $>35$ & \multirow{7}{*}{$\begin{array}{l}\text { Anti B } \\
\text { \& } \\
\text { anti A* }\end{array}$} \\
\hline $\mathrm{A}_{3}$ & $++\mathrm{mf}$ & 0 & $++m f$ & $3+$ & 0 & $+1-$ & Yes & $A, H$ & sometimes & 35 & \\
\hline$A_{x^{\prime}}$ & $W k / 0$ & 0 & $2+$ & $4+$ & 0 & always & Yes & $\mathrm{A}$ (trace), $\mathrm{H}$ & rarely & 5 & \\
\hline$A_{\text {end }}$ & $\mathrm{mf} / \mathrm{w}$ & 0 & $\mathrm{w} / \mathrm{mf}$ & $4+$ & 0 & & Yes & $\mathrm{H}$ & no & 3.5 & \\
\hline$A_{m}$ & $0 / w k$ & 0 & $0 /+$ & $4+$ & 0 & no & Yes & A, $\mathrm{H}$ & yes & 1 & \\
\hline Ay & 0 & 0 & 0 & $4+$ & 0 & no & Yes & A, $\mathrm{H}$ & trace & 1 & \\
\hline$A_{e l}$ & 0 & 0 & 0 & $4+$ & $+/-$ & yes & Yes & $\mathrm{H}$ & NO & 0.7 & \\
\hline
\end{tabular}

*(weak, rare \& usually cold)

As shown in table 1 , the weak " $A$ " subgroups are: $A_{2}, A_{3}, A_{x^{\prime}} A_{\text {end }}, A_{m}$, Ay\& $A_{e l}^{4}$. Only $A_{2}, A 3, A_{x}$ and $A_{\text {end }}$ show agglutination with the anti-seras. "A2" subgroup shows $+2,+3$ agglutination with anti-A, A3 shows a mixed field agglutination with anti $A$, while in $A_{\text {end }}$ only $10 \%$ cells show weak mixed field agglutination whereas $A_{x}$ shows only weak reaction with $A B$ antisera only. The other subgroups $A_{m^{\prime}}$ Ay \& $A_{e l}$ do not show any reaction with " $A$ " antisera ${ }^{5}$. These groups may have naturally occurring cold antibodies but may develop immune anti-A1 antibodies reactive at 37 $C$ if transfused with "A1" blood group 6 . Acquired " $B$ " antigen is not an uncommon phenomenon especially in malignancies of gut and in severe infections ${ }^{7}$. The bacterial produce a deacetylase (enzyme) which chemically modifies the terminal sugar of " $\mathrm{A}$ " antigens ( $\mathrm{N}$-acetyl-D-galactosamine) into $D$-galactosamine. Because the terminal sugar of the " $B$ " antigen is galactose, anti- $B$ antisera will cross react with the B-like D-galactosamine antigen ${ }^{8}$. As this phenomenon is in vivo, only group " $A$ " people can develop an acquired B-like antigen. The condition is transient and disappears when the infection is cured and do not pose any transfusion risks except creating discrepancy in $A B O$ grouping. These acquired $B$ antigens are not secreted in saliva and this investigation is useful in differentiating it with rare B subgroups. In vitro, blood specimens can develop an acquired B-like antigen if they are bacterially contaminated. This is because the membranes of some bacteria (e.g., E. coli and P. vulgaris) have determinants that are chemically similar to the B antigen ${ }^{9}$. In this case,
anti-B antisera actually react with the bacterial antigens which have attached to the red cells. In vitro, both group $\mathrm{O}$ and group " $\mathrm{A}$ " cells can acquire the B-like antigen. Important to note is that most examples of acquired " $B$ " phenomenon detected in the blood bank happen in vivo to group " $\mathrm{A}$ " people only.

\section{Case Report:}

Blood sample of 87-year-old woman was received by GIH blood bank with a request for two compatible PRBCs. She was a diagnosed case of Urinary Tract Infection and on antibiotic treatment. She was somewhere else labeled as " $A B$ " Positive blood group. As a routine, her blood group was reconfirmed by repeat testing and a significant discrepancy was found as shown in table 2.

As this patient had a discrepancy, the negative reactions were also verified microscopically. It was found that in addition to mixed field reaction with anti " $A$ " and " $A B$ " sera, this patient had a microscopic positive reaction with anti $B$ sera along with strong reaction with $B$ known cells and no reaction with $A$ cells on serum grouping. This patient was then tested with A1 lectin which was positive and anti- $\mathrm{H}$ which was positive. Auto control with her cells and plasma was also tested and that was reactive. This raised the suspicion that probably the patient has developed auto antibodies on a background. To confirm the presence of acquired " $B$ " antigen, the antisera " $\mathrm{B}$ " was acidified with $\mathrm{HCl}$ to keep $\mathrm{pH}$ just above 
Nepal, et al. / Acquired B antigen in ABO blood group system: Non-secretor group 'A1'subtype, Rh positive with auto antibodies in a patient with urinary tract infection with $\mathrm{E}$. coli

Table 2: Blood group reactions of patient

\begin{tabular}{|l|c|c|c|c|c|c|c|c|c|c|}
\hline & \multicolumn{4}{|c|}{ Forward grouping } & \multicolumn{3}{c|}{ Auto- } & \multicolumn{3}{c|}{ Reverse grouping } \\
\cline { 2 - 12 } & Anti A & Anti B & Anti AB & Anti D & Anti H & A1 Lectin & control & A cells & B cells & O cells \\
\hline Macroscopic & +2 & +1 & +2 & +4 & +3 & +4 & +1 & Neg & +4 & Neg \\
\hline Microscopic & +2 & +2 & +2 & +4 & +3 & +4 & +1 & Neg & +4 & 00 \\
\hline
\end{tabular}

6.0. The sample did not react with this acidified antiserum. Adsorption elution for B antibodies was also negative. Her saliva did not contain any "A", "B" or " $\mathrm{H}$ " antigen.

Cross match with "A1" blood group showed compatible both in saline and AGT phase. Keeping in view the mixed field reaction with " $A$ " \& " $A B$ " antisera and strong reaction with $\mathrm{A} 1$ lectin antisera, her blood group was assumed to be of "A1" phenotype. As this patient had auto antibodies and "A1" blood group was available so her blood was cross matched with A1 positive blood group and she was transfused with this group without any transfusion reactions.

\section{Discussion:}

" $A$ " and " $A B$ " have many sub-groups identified until now. " $A$ " subgroup carries less amount and slightly different antigens due to allelic differences. These sub-groups secrete fewer amounts of antigens in the saliva. Sometimes they harbor naturally occurring anti A1 in them but as these are cold antibodies so they do not pose any transfusion risk, but can develop anti A1 if exposed to A1 blood group which are usually $\lg G$ and reactive at $37^{\circ} \mathrm{C}$ causing problems in compatibility testing and may produce immune transfusion reactions ${ }^{10}$. Subgroups of " $A$ " are more commonly encountered than subgroups of "B" (AABB technical manual) which are $B 3, B x \&$ Bel. All subgroups are characterized by decreasing numbers of antigen sites on the red cells and reciprocal increase in $\mathrm{H}$ antigen activity. Subgroups are more often recognized when there is a discrepancy between the red cells and serum grouping. Some blood banks perform only forward grouping and these results are not confirmed by serum grouping. Moreover, they perform grouping by slide method in which weak antigens are not detected and as a result the persons are typed wrongly. Acquired " $B$ " antigen is not an uncommon finding and as the case here is sometimes found in malignances of gut ${ }^{11}$ and may also be seen in severe bacterial infections when the bacterial enzymes convert the normal antigen to $B$ antigen on the surface of red cell.

When a subgroup is encountered it is always appropriate to determine the secretor status of that person, as these antigens are secreted in saliva, as more than $80 \%$ individuals are secretors ${ }^{8}$. It is also necessary to check all " $A$ " and " $A B$ " groups with $A 1$ lectin, as $A 2$, sometimes $A 3$ and usually other A sub groups can be missed. We also recommend confirming any negative reaction in cell and serum grouping by microscopic examination, as the antigen may be too weak to show a macroscopic reaction.

\section{Conclusions:}

Usually these subgroups are wrongly typed as "O", which may cause HTR (Hemolytic Transfusion reaction), even leading to death. All negative reactions should be confirmed by microscopic examination. All " $A$ " and " $A B$ " groups should be tested with "A1" lectin and if negative, should be checked in by anti-H antisera. Adsorption elution test and secretor status of the sub-group person can be helpful in confirming the subgroups.

In cases of subgroups, a proper three phase cross match should be done - saline phase at room temperature, $4^{\circ} \mathrm{C}$ and $37^{\circ} \mathrm{C}$ temperature, ICT phase to ensure correct blood to the right patient.

\section{References}

1. Yip SP. Sequence variation at the human $A B O$ locus. Ann Hum Genet. 2002 Jan;66(Pt 1):1-27

2. Pipatvanichkul A, Permpikul P, Vejbaesya S, Chinswangwatanakul W. Mutation of ABO gene in Thai blood donors with A3 phenotype. J Med Assoc Thai. 2011;94(3):379-85

3. Cartron JP, Gerbal A, Hughes-Jones NC, Salmon C. 'Weak A' phenotypes. Relationship between red cell agglutinability and antigen site density. Immunology. 1974;27(4):723-7. 
4. Yamamoto F, Clusen H, White T, Marken J, Hakomori S. Molecular genetic basis of the histo-blood group ABO System. Nature 1990; 345(6272): 229-33.

5. Heier HE, Namork E, Calkoska Z, Sandin R, Kornstad L. Expression of $A$ antigens on erythrocytes of weak blood group A subgroups. Vox Sang. 1994;66(3):231-6.

6. Lee $A H$, Reid ME. ABO blood group system: $A$ review of molecular aspects. Immunohematology. 2000;16(1):1-6.

7. Gerbal A, Ropars C. [Acquired B antigen] Rev $\mathrm{Fr}$ Transfus Immunohematol. 1976 Mar;19(1):127-44. [In French]
8. Harmening, DM: Modern Blood Banking and Transfusion Practices, 5th ed. FA Davis, Philadelphia, PA, 2005.

9. Dean L, National Center for Biotechnology Information (US). Blood groups and red cell antigens. 2005. Available at http://www.ncbi.nlm. nih.gov/books/NBK2267/

10. Economidou J, Hughes-Jones NC, Gardner B. Quantitative measurements concerning $A$ and $B$ antigen sites. Vox Sang. 1967;12(5):321-8.

11. Thakral B, Saluja K, Bajpai M, Sharma RR, Marwaha N. Importance of Weak ABO Subgroups. Lab Med. $2005 ; 36(1): 32-4$. 